\title{
NOTE
}

\section{Induction of Specific Human Growth Hormone Binding Sites in Rat Liver by Human Growth Hormone}

\author{
Kazue TAKano, Naomi hizUKa, Koichi KaWAi, \\ AND KazUo SHIZUME \\ Department of Medicine Tokyo Women's Medical College \\ Shinjuku-ku, Tokyo 162, Japan
}

\begin{abstract}
Synopsis
${ }^{125}$ I-Labeled hGH was bound to liver plasma membranes which were obtained from female rats. The binding was displaced by hGH, hPRL, bPRL, rPRL and bGH but not by $\mathrm{rGH}$. This result indicated that $\mathrm{hGH}$ was bound to lactogenic binding sites in rat livers. After hypophysectomy, the binding was markedly decreased. Treatment of hypophysectomized rats with hGH $(80 \mu \mathrm{g} /$ day $)$ for 10 days increased the binding sites for hGH. These binding sites were different from those found in normal female rat livers because of their high affinity and specificity for hGH. These results indicate that hGH induces specific binding sites for hGH in rat livers.
\end{abstract}

The initial step in the action of polypeptide hormone is binding to specific receptors on the surface of target cells. Recently, the binding of ${ }^{125}$ I-labeled $\mathrm{hGH}$ to cell membranes prepared from livers of rabbits, rats and other species has been reported (Tsushima and Friesen, 1973; Posner et al., 1974; Kelly et al., 1974; Carr and Friesen, 1976; Posner, 1976a). Binding to liver membranes could only be demonstrated by using female or estrogen-treated male rats. In these membrane preparations, ovine prolactin was identical with hGH in displacing labeled bound-hGH (Posner et al., 1974). It has been reported that $\mathrm{hGH}$ binding to rat liver membranes was decreased by hypophysectomy and restored by renal implantation of pituitaries (Posner et al., 1975; Posner, 1976b), but was not increased by treatment with bGH (Herington et al., 1976a). Therefore, whether hGH played a role in inducing its own binding site in rat livers was investigated in the present study.

Received October 16, 1978.

\section{Materials and Methods}

Normal male and female Sprague-Dawley rats were used and were divided into 3 groups: Group I consisted of 5 male and 5 female rats of 52 days old which were used as controls; Group II consisted of 4 male and 6 female rats which were hypophysectomized at 28 days of age and were sacrificed 24 days later; Group III consisted of 4 male and 6 female rats which were hypophysectomized at 28 days of age and to which hGH was administered ip $80 \mu \mathrm{g}$ per day for 10 days beginning on the 40th day and which were sacrificed on the 52nd day. At the time of sacrifice, livers and kidneys were quickly removed and kept frozen $\left(-70^{\circ} \mathrm{C}\right)$ until studied.

Rat livers or kidneys were homogenized in $0.25 \mathrm{~mol}$ per liter ice-cold sucrose and crude membranes were prepared by stepwise ultracentrifugation according to the method described by Cuatrecasas (1972). The membrane fraction sedimenting between $12,000 \times g$ and $40,000 \times g$ was used for the binding study.

Hormone binding was measured in triplicate in a reaction mixture consisting of $100 \mu l 0.05 \mathrm{~mol}$ per liter Tris- $\mathrm{HCl}$ buffer containing 1\% human serum albumin with or without unlabeled hormone, 100 $\mu l$ membrane preparation ( $250 \mu \mathrm{g}$ protein), and $100 \mu l{ }^{125} \mathrm{I}-\mathrm{hGH}(20,000 \mathrm{cpm})$. In some experiment indicated in the results, pooled membranes were used. After $16 \mathrm{hr}$ of incubation at $4^{\circ} \mathrm{C}$, bound and free hormones were separated by centrifugation at $6,000 \times$ $g$ for $15 \mathrm{~min}$, and membrane-bound ${ }^{125} \mathrm{I}-\mathrm{hGH}$ in the 
pellet was counted in a well-type gamma spectrometer. The binding of labeled hGH was time- and temperature-dependent. At $4^{\circ} \mathrm{C}$, the maximal binding was obtained after $16 \mathrm{hr}$ when $12 \%$ of the total activity was bound.

Protein concentration was determined by the method of Lowry et al. (1951).

A preparation of $\mathrm{hGH}$, Crescormone (R), from AB Kabi/Recip, Stockholm, Sweden, was used for injection and assay of hGH. This preparation contains $2 \mathrm{IU}$ per $\mathrm{mg}$ of $\mathrm{hGH}$ and is essentially free from ACTH, FSH, LH, TSH, vasopressin, oxytocin and polymers of $\mathrm{GH}$. Other hormones used were: bovine GH (NIH-GH-B18); rGH (NIAMD-RAT GHB-4); bPRL (PROLACTIN, BOVINE, NIH-P-B4); rPRL (NIAMDD-RAT PROLACTIN-B-1). Human GH (NIH-GH-HS 2160E) and hPRL (NIH-hPRLVLS-4) were iodinated by the chloramine-T method (Hunter and Greenwood, 1962) with a specific activity of $100 \pm 50 \mu \mathrm{Ci} / \mu \mathrm{g}$ and $50 \pm 10 \mu \mathrm{Ci} / \mu \mathrm{g}$, respectively.

\section{Results}

The binding of ${ }^{125} \mathrm{I}-\mathrm{hGH}$ to liver membrane was a saturable process with respect to the increased membrane concentration in the medium. Membranes prepared from normal female and male rats bound $10.8 \pm$ 2.5 and $2.2 \pm 0.15 \%(\text { mean } \pm \mathrm{SEM})^{125} \mathrm{I}-\mathrm{hGH}$, respectively, when $1 \mathrm{mg} / \mathrm{ml}$ membrane protein was used. A significant displacement was obtained with $3.3 \mu \mathrm{g} / \mathrm{ml}$ of $\mathrm{hGH}$ in normal female rat livers but not in male rat livers indicating that the binding of ${ }^{125} \mathrm{I}-\mathrm{hGH}$ to male rat liver was not specific. There were no specific binding sites for hGH to kidney membranes obtained from normal male and female rats.

After hypophysectomy (Group II), the binding of ${ }^{125} \mathrm{I}-\mathrm{hGH}$ to liver membranes per $\mathrm{mg}$ protein of female rats decreased to 2.8 $\pm 0.18 \%$ which was not significantly displaced by $3.3 \mu \mathrm{g} / \mathrm{ml}$ of $\mathrm{hGH}$. There was no change in the binding of ${ }^{125} \mathrm{I}-\mathrm{hGH}$ to liver membranes obtained from hypophysectomized male rats. After hGH treatment for 10 days, the binding of ${ }^{125} \mathrm{I}-\mathrm{hGH}$ to liver membranes per $\mathrm{mg}$ protein increased in livers obtained from both female and male rats from $2.8 \pm 0.18$ and $2.6 \pm 0.11$ to $8.5 \pm 1.6$ and $11.8 \pm 2.1 \%$, respectively. No significant difference for ${ }^{125} \mathrm{I}-\mathrm{hGH}$ binding to liver membranes was observed between hGH-treated male and female rats. There was no specific binding of $\mathrm{hGH}$ to the kidney membranes obtained from Group II and III.

The ${ }^{125} \mathrm{I}-\mathrm{hGH}$ bound to normal female rat livers was displaced by hGH. A linear logdose-response curve was obtained between 13 and $833 \mathrm{ng} / \mathrm{m} l$ in normal female rat livers (Fig. 1). Human PRL, bPRL and rPRL in similar doses also displaced ${ }^{125} \mathrm{I}-\mathrm{hGH}$ from its binding sites. Bovine $\mathrm{GH}$ in larger doses displaced ${ }^{125} \mathrm{I}-\mathrm{hGH}$ from its binding sites; however, rGH did not displace ${ }^{125}$ IhGH even when a concentration of 167 $\mu \mathrm{g} / \mathrm{m} l$ was used. The Scatchard plot (Scatchard, 1949) of the binding of $\mathrm{hGH}$ to liver membranes from normal female rats was concave. Assuming two classes of binding sites, the affinity constant and capacity of high affinity binding sites were $2.3 \pm 0.05 \times 10^{8} \mathrm{M}^{-1}$ and $602.6 \pm 142 \mathrm{fmole} / \mathrm{mg}$ protein, respectively,

The ${ }^{125} \mathrm{I}-\mathrm{hGH}$ bound to liver membranes

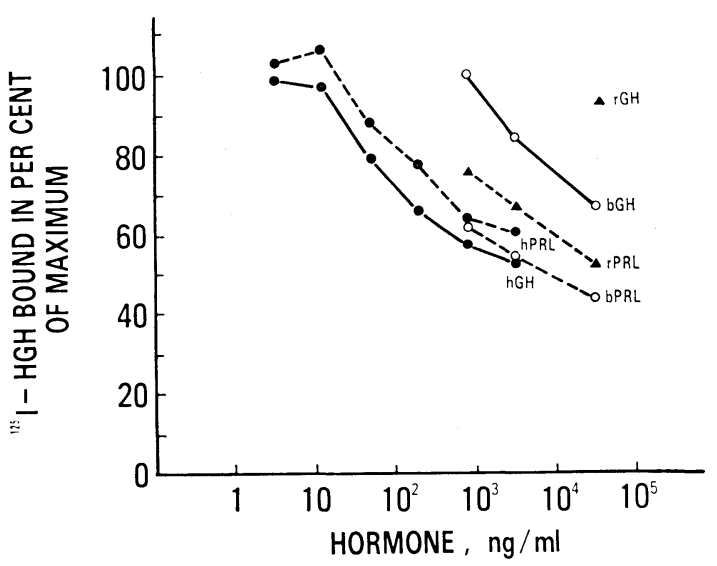

Fig. 1. The effect of hGH, bGH, rGH, hPRL, bPRL and $\mathrm{rPRL}$ on the binding of ${ }^{125} \mathrm{I}-\mathrm{hGH}$ to pooled liver membranes $(800 \mu \mathrm{g} / \mathrm{ml}$ membrane protein used) from normal female rats. Nonspecific binding was not subtracted. Each point shows the mean of the triplicate. 
obtained from hGH-treated male and female rats was displaced by $\mathrm{hGH}$ and a linear logdose-response curve was obtained between 0.81 and $52 \mathrm{ng} / \mathrm{ml}$. (Fig. 2). The dose of $\mathrm{hGH}$ required for $50 \%$ displacement of ${ }^{125} \mathrm{I}-\mathrm{hGH}$ was 150 times less than that required in normal female rat livers. Human prolactin in high doses was able to displace ${ }^{125} \mathrm{I}-\mathrm{hGH}$ from its binding sites; however, rGH, bGH, rPRL and bPRL did not displace ${ }^{125} \mathrm{I}-\mathrm{hGH}$ even when concentrations as high as $33 \mu \mathrm{g} / \mathrm{m} l$ were used as shown in Fig. 2. The Scatchard plot of the binding of hGH was concave also in the hGH-treated rats. Assuming two classes of binding sites, the calculated affinity constant of high-affinity binding sites in female and male rats were $1.07 \pm 0.19$ and $1.30 \pm 0.07 \times 10^{9} \mathrm{M}^{-1}$, respectively, and there were $111.2 \pm 14.1$ and $90.3 \pm 16.4$ fmoles of binding sites per $\mathrm{mg}$ of membrane protein, respectively. There was no significant difference in these parameters between female and male rats.

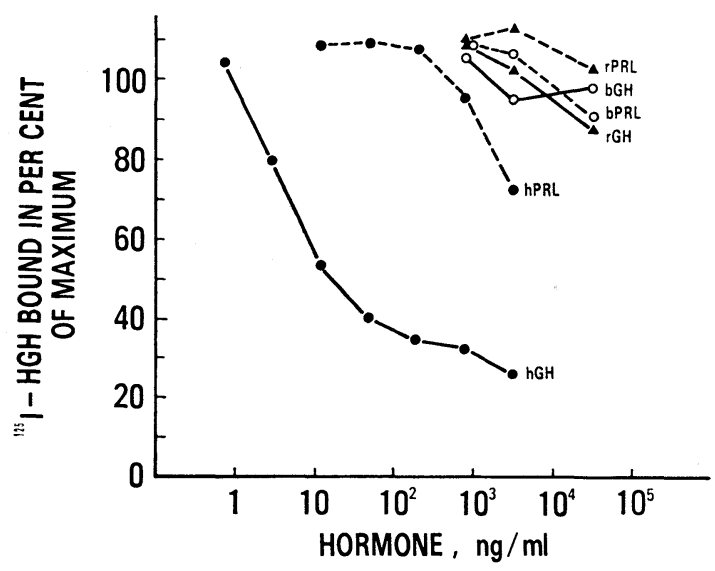

Fig. 2. The effect of hGH, bGH, rGH, hPRL, bPRL and rPRL on the binding of ${ }^{125} \mathrm{I}-\mathrm{hGH}$ to pooled liver membranes $(800 \mu \mathrm{g} / \mathrm{m} l$ membrane protein used) from hGH-treated male rats. Nonspecific binding was not subtracted. The point shows the mean of the triplicate.

\section{Discussion}

In this study specific binding sites of $\mathrm{hGH}$ in liver membranes of normal female rats were demonstrated, which decreased after hypophysectomy. It was also shown that different binding sites were induced by the administration of hGH to hypophysectomized rats.

Human GH has a potency of both somatogenic and lactogenic effect. The binding of hGH to liver membranes from normal female rats was the result of binding to lactogenic sites, which was observed only in female rats and was similarly displaced by hGH, hPRL, bPRL and rPRL. These results confirmed earlier reports by others (Posner et al., 1974; Herington et al., 1976b). The binding of hGH was also displaced by bGH. However, higher doses of bGH were required in comparison with those of bPRL to get the same amount of displacement of ${ }^{125} \mathrm{I}-\mathrm{hGH}$. Therefore, we think the displacement of bGH resulted from bPRL which was contaminated in this bGH preparation.

The binding sites of hGH in liver membranes induced by $\mathrm{hGH}$ treatment in hypophysectomized rats were quite different from those of normal female rats in their specificity and affinity. The affinity constant was five times higher in comparison to that of the binding sites of hGH in normal female rats. They were not significantly displaced by bGH, bPRL, rGH and rPRL at the concentration used in this study. Human PRL interfered with this binding site, but were about 1000 times higher doses of hPRL were required to get the similar displacement compared with those of hGH. Furthermore, ${ }^{125}$ I-hPRL did not bind to this binding site (data not shown). Therefore, the binding site was not a lactogenic site. The displacement of this binding site by hPRL might be because of the contamination of hGH in hPRL pre- 
paration. However, the direct effect of be elucidated. hPRL on this binding sites was also probable.

We have concluded that high affinity, low capacity binding sites specific for $\mathrm{hGH}$ were induced by $\mathrm{hGH}$ and this binding site was only interfered by hPRL in higher concentration. Other pituitary hormones besides $\mathrm{hGH}$, which were contained in this $\mathrm{hGH}$ preparation used in this study, might induce this specific binding sites. However, contamination with other pituitary hormones was negligible, thus the possibility was extremely unlikely.

Contamination of antibody against hGH in membrane fraction might produce similar findings. However such specific binding was observed only in liver membranes and not in kidney membranes which were obtained by the same procedures. This result ruled out the above possibility.

Binding sites for insulin in various tissues were observed to be decreased during chronic elevation of insulin levels (Kahn et al., 1973; Gavin et al., 1974). Similar results were obtained in the studies of the effect of hGH on lymphocyte hGH receptors (Lesniak et al., 1974). However, Posner (1976b) reported the chronic elevation of prolactin-induced specific lactogenicbinding sites in rat livers. Herington et al. (1976a) reported that treatment of hypophysectomized rats with $500 \mu \mathrm{g}$ of bGH for 5 days did not result in the increased binding of ${ }^{125} \mathrm{I}-\mathrm{hGH}$ to liver membranes. We did not find increased hGH-binding in livers of hypophysectomized rats treated with $500 \mu \mathrm{g}$ of $\mathrm{rGH}$ for 5 days (unpublished data). On the other hand, we have found that hGH induced specific hGHbinding sites in rat livers. Tsushima et al. observed that hGH, but not bGH or hPRL induced binding sites for $\mathrm{hGH}$ in rabbit livers (Tsushima, 1976, 1977). These data suggest that the induction of hGH binding sites is specific for hGH. However, the physiological role of this finding is yet to

\section{Acknowledgements}

The authors thank Dr. A. Takagi of Dainabot Company for providing us the labeled $\mathrm{hGH}$ and hPRL.

This study was supported by a Research Grant from the Intractable Diseases Division, Public Health Bureau, Ministry of Health and Welfare, Japan.

\section{References}

Carr, D. and H. G. Friesen (1976). J. Clin. Endocrinol. Metab. 42, 484.

Cuatrecasas, P. (1972). Proc. Natl. Acad. Sci. USA $69,318$.

Gavin, J. R., J. Roth, D. M. Neville, Jr., P. DeMeyts and D. N. Buell (1974). ibid. 71, 84.

Herington, A. C., L. S. Phillips and W. H. Daughaday (1976a). Metabolism 25, 341.

Herington, A. C., N. Veith and H. G. Burger (1976b). Biochem. J. 158, 61.

Hunter, W. H. and F. C. Greenwood (1962). Nature 194, 495.

Kahn, C. R., D. M. Neville, Jr. and J. Roth (1973). J. Biol. Chem. 248, 244.

Kelly, P. A., B. I. Posner, T. Tsushima and H. G. Friesen (1974). Endocrinology 95, 532.

Lesniak, M. A., A. R. Bianco, J. Roth and J. R. Gavin III (1974). Clin. Res. 22, 343 A.

Lowry, O. H., N. J. Rosebrough, A. L. Farr and R. J. Randall (1951). J. Biol. Chem. 193, 265.

Posner, B. I. (1976a). Endocrinology 98, 645.

Posner, B. I. (1976b). ibid. 99, 1168.

Posner, B. I., P. A. Kelly and H. G. Friesen (1974). Proc. Natl. Acad. Sci. USA 71, 2407.

Posner, B. I., P. A. Kelly and H. G. Friesen (1975). Science 188, 57.

Posner, B. I., P. A. Kelly, R. P. C. Shiu and H. G. Friesen (1974). Endocrinology 95, 521.

Scatchard, G. (1949). Ann. N.Y. Acad. Sci. 51, 660.

Tsushima, T. and H. G. Friesen (1973). J. Clin. Endocrinol. Metab. 37, 334.

Tsushima, T. (1976). Folia. Endocrinol. Japon. 52, 259, (Abstract, in Japanese).

Tsushima, T. (1977). Clin. Endocrinol. (Tokyo) 25, 143, (In Japanese). 